\section{GOMBOS Péter}

Kaposvári Egyetem Pedagógiai Kar Magyar Nyelvi és Kultúratudományi Tanszék

ORCID: 0000-0002-8172-0557

\section{NÉMETH Csenge Rózsa}

Kaposvári Egyetem Pedagógiai Kar

Magyar Nyelvi és Kultúratudományi Tanszék

\section{Sárkánykép}

a magyar népmesekincsben Egy kontamináció anatómiája

Kutatásunk során azt szerettük volna megtudni, hogy a magyar népmesékben, illetve általánosabban a magyar néphitben milyen módon jelenik meg a sárkány alakja. Szúkebben arra voltunk kíváncsiak, hogy hogyan, mikor keveredett össze az állatszerü (gyíkszerü), tüzfújó szörnyeteg és a lányrabló (férfiszerü) mesealak figurája. Sejtésünk az volt, hogy eredendően e két sárkánytípus külön (történetekben) létezett, s csak később mehetett végbe az a kontamináció, amelynek eredményeként ma már nem csodálkozunk rá arra, miért is rabol magának feleséget egy repülö, tüzfújó gyíkszörny.

Kutatásunkhoz az első, még 19. századi magyar népmesegyüjtemények közül Arany László, Benedek Elek, Berze Nagy János, Erdélyi János, Ipolyi Arnold, Kriza János, Mailand Oszkár és Merényi László gyüjtéseit tekintettük át. Az ezekben talált sárkányos meséket csoportosítottuk a bennük előforduló sárkányok alakjai szerint, s a kapott eredmények alapján fogalmaztunk meg következtetéseket a keveredés idejét és mikéntjét illetően.

Kulcsszavak: népmese, sárkánykép, kontamináció, Benedek Elek

\title{
Célkitüzés
}

Kutatásunk során azt szerettük volna megtudni, hogy a magyar népmesékben, illetve általánosabban a magyar néphitben milyen módon jelenik meg a sárkány alakja. Különösen arra a feltevésre kerestünk igazolást, hogy a magyar népmese sárkánya emberszerü, antropomorf lény is lehet, sőt hogy több esetben olyan történetekben vált gyíkszerű szörnyeteggé, amelyben eredendően emberi attribútumokkal rendelkezett. Természetesen az is érdekes kérdés volt számunkra, hogy vajon kideríthető-e, mikor és hogyan változott meg egy-egy konkrét mese sárkányalakja, illetve általában a sárkányképünk.

Kutatásunkhoz az első, még 19. századi magyar népmesegyűjtemények közül Arany László, Benedek Elek, Berze Nagy János, Erdélyi János, Ipolyi Arnold, Kriza János, Mailand Oszkár és Merényi László gyűjtéseit tekintettük át. Az ezekben talált sárkányos meséket csoportosítottuk a bennük előforduló sárkányok alakjai szerint. A csoportosításkor a sárkány kinézete és „életmódja” (szerepe) volt számunkra a fő szempont. 


\section{Mesegyứjtő vs. meseíró?}

Laikusok számára meglepőnek tűnhet a felvetés: 19. századi (úttörő) mesegyűjtőink nem kezelték „kellő tisztelettel” a fölgyűjtött szövegeket? Akár jelentős átírások is elképzelhetők az általuk hallott és a nyomtatásban megjelent anyagok között?

Valójában már a kérdés sem helytálló. A kor tudományos szellemiségével korántsem volt ellentétben az az attitűd, hogy a gyűjtött mesékre alapanyagként tekintsenek a szerzők, ez tehát nem a tiszteletlenség vagy a hanyagság jele volt. E tanulmánynak nem tárgya azt megállapítani, hogy melyik gyưjtő törekedett a legpontosabban visszaadni az orális folklór kincseit írásban is, néhány állítást teszünk csupán, amelyek fontosak témánk szempontjából. A problémáról a hivatkozott munkákban részletesebb elemzés is olvasható.

Aligha lényegtelen a témában Arany János véleménye: „A jó gyüjtő mindenek felett egy tökéletes mesemondó képességeivel legyen felruházva. [...] Az előadási, öltöztetési modor annyira hatalmában álljon, hogy ha valamely mesének puszta vázát kapná, képes legyen azt olyanná tenni, mintha a legjobb mesemondó ajakáról vette volna." (Arany 1861: 7)

Valójában már a kezdetektől ez a hozzáállás volt jellemző, az első magyar (bár német nyelven megjelent) gyűjtemény, Gaál György Märchen der Magyaren című kötetének fordítója-szerkesztője, Kazinczy Gábor is a kor elvárásainak megfelelően bánt az idegen szavakkal, többnyire átírta azokat, ha nem is mindet:

„Némely idegen szavakat meghagytam, mert jellemző pl. purgerság, gulranz, patrol.” (idézi: Domokos 2005)

Ugyanakkor Kazinczy megpróbálta megőrizni az élő szavas mesemondás sajátosságait:

„A magyar mesei előadó sajátsága, hogy ismételgeti azt (beszélgetés közben), mit a hallgató vagy olvasó már tud, de az, akinek ott elmondatik, nem tudhat. Erdélyi összehuzta ezt pedig tilos." (idézi: Domokos 2005)

S mert e történeteket már gyerekeknek szánták, különös figyelem került a durva, alpári kifejezésekre, Toldynak ezt írta a szerkesztő:

„Némely frivolabb kifejezést meg kelle lágyítanom. P 124. a szeretőm segge partja. Te talán azt is sokalni fogod ami megmarad. Ne feledd, hogy kocsis élcze." (idézi: Domokos 2005)

Kortársaihoz képest üdítő kivételnek számított Kriza János, aki alapelvéről így vallott: „Lassan tisztult bennem a gondolat, úgy adni ki a népkölteményeket s szólásmódokat, oly hangejtéssel, épen mint a nép kiejti - a virágot egész hímével, illatával mutatni be a közönségnek - a plántát úgyszólva azonmódulag, mint a természet anyakeblén felvirult, állítni elé." (Idézi Domokos 2008: 244)

Érdekes, hogy mindezek ellenére Krizát Horger Antalék azzal vádolták, hogy az eredeti szövegkorpuszon komolyabb stilizálásokat hajtott végre. Ám például Erdélyi Lajos és Sebestyén Gyula határozottan cáfolta ezt. Ezt az álláspontot erősítheti az is, hogy - Domokos Mariann több meggyőző érvvel támasztja ezt alá - Kriza meséinek lejegyzője elsősorban az a Marosi Gergely lehetett, aki nyelvészeti érdeklődése miatt jobban figyelt a nyelvi sajátosságokra, s bizonyosan kevésbé volt motivált a szöveg stilizálására, megváltoztatására (Domokos 2008). Ugyancsak erre utal az a tény is, hogy - sokakkal ellentétben - Marosi még az alpáriságot sem hagyta ki vagy finomította (Domokos 2008).

Ugyancsak az eredetiségre törekvést szokták emlegetni Kálmány Lajos kapcsán. Kovács Ágnes - a téma kiváló kutatójának - véleménye azonban árnyalja ezt a képet: „Kálmány szövegei sem hitelesebbek, mint Aranyéi vagy Krizáé, csak - rosszabbak" (Kovács 1961: 432). 
Nagyjából hasonló az értékelése Merényi Lászlónak és Sebestyén Gyulának is, de Arany László esetében is hasonló a helyzet, csak ott az is bonyolítja a dolgot, hogy még a szerző személyében sem lehetünk bizonyosak. (Lásd erről bővebben: Domokos-Gulyás 2009; Gombos 2017)

Más utat járt Mailand Oszkár, aki saját bevallása szerint: „Ezeket minden kihagyás, toldás vagy átalakítás nélkül úgy közlöm, miként a mesélő ajkáról feljegyeztem, mert ha az ősi felfogás, hit és nyelvezet ezen legfontosabb forrásain változtatunk, önmagunkat csaljuk meg." (Mailand 1905, XXVI)

Hasonló célkitűzéssel dolgozott Berze Nagy János is, ám Kovács Ágnes az ő szövegeiről is azt állapítja meg, hogy annyira egyforma a stílusuk, a hangjuk, hogy ez önmagában is mutatja, Berze Nagy nem csupán közreadója, de formálója is volt a meséknek (Kovács 1961).

Benedek Elekről később részletesebben is szólunk, most egy rövid idézettel bizonyítanánk csak hozzáállását a munkához, a korábban ki nem adott Kriza-kéziratok feldolgozása kapcsán: „...midőn ezeknek az újraírása szükségessé vált, ez nem jelenti [...] hogy az újraíró kiforgatta a meséket igazi karakterükből, egyszerűen az igazi mesemondó hangját próbálta belevinni csekélységem: azt a hangot, mely bennük volt, mikor a mesemondó elmesélte, de amit visszaadni a gyűjtő nem tudott." (Benedek Eleket idézi Kovács 1961: 436)

E rövid áttekintéssel azt szerettük volna bizonyítani, hogy a gyűjtők többsége szabadon kezelte a felgyűjtött szövegeket. Később azt is megmutatjuk, hogy a gazdagítás, színesítés szándéka aztán komoly torzulást is okozhatott a mesékben, például az azokban kirajzolódó sárkányképben.

\section{A néphit és a népmese kapcsolata}

Mielőtt a konkrét mesékre kitérnénk, fontos tisztáznunk a népmese és a néphit kapcsolatát. A népmesék már régen is fiktív történetnek számítottak, ellenben a néphit mítoszait reális, létező esetekként tartották számon (Dömötör 1981). Ugyanakkor fontos tény az is, hogy a népmese nem tudott volna létrejönni a hiedelemvilág elemei nélkül. „Nem győzzük hangsúlyozni, hogy a mesei világot mennyire meghatározza a hiedelemvilág. Utóbbi táplálja előbbit, vagy utóbbi képezi azt a talajt, amelyen előbbi kisarjad. Megfosztva ettől a talajtól, elsorvad a mesei elem is." (Nagy 1974: 67) Tehát azok a jelentéstartalmak, amelyek a népmesei szereplőkhöz, cselekedetekhez kapcsolódnak, egy mögöttes világnézetből gyökereznek, amely lehetővé teszi a mese megértését.

A meseszereplőket és a néphit mitikus alakjait ugyanazzal a szóval jelölik, de tulajdonságaik, szerepeik és valóságértékük nem egyeznek meg. A sárkány például a népi hiedelemben állatszerű lény, de a népmesékben olykor emberként is viselkedik, a táltos szó pedig a néphitben egy embert jelöl (sámán, gyógyító), a népmesékben viszont lovat (táltos paripa) is jelölhet. A névazonosság jellemzően érzékelteti a lények pozitív vagy negatív voltát, például az ördög, a boszorkány a néphitben és a népmesében egyaránt gonosz alakok. De ez nem minden esetben van így, példának okáért a tündérek a meséinkben általában pozitív szereplők, hiedelmeinkben viszont inkább veszélyes, bajt okozó alakok (Dömötör 1981).

A sárkányokba vetett néphitet a különféle regéken kívül a hely- és helységnevek is örökítik. Sok megyében találni például Sárkány nevű települést. A sárkányos helynevek közül nagyon beszédes például Sárkányrugás (egy gödrös legelő Pécel határánál), Sárkányheverés (Dömsödnél), Öreg-Sárkányfark (dűlő), Sárkányjárás - árok, ahol a história szerint egy sárkány egy Jolán nevű szép lányt belefojtott a Kerka vizébe (Kandra 1897). 
A 'sárkány' szavunk egyébként feltehetően ótörök eredetű jövevényszó, amely már a XII. századtól megtalálható magyarországi írásos emlékekben, főleg helynevekben, mint a Sárkányhegy (XIII. század), Sárkányosfő (XIII. század), Sárkány ároka (XV. század) (Dömötör 1981). A szó töve valószínűleg „sziszegő”-t, „mérges köpésű”-t jelentett, amely kifejezések a kígyóra engednek következtetni. Azonban ehhez az alapjelentéshez egy egész fogalomkör kapcsolódik, amely a mitikus hagyományok révén füződött hozzá a szóalakhoz (Solymossy 1931). Az idők során számos olyan népi históriát, babonát gyűjtöttek össze, amelyekben a lény feltünik.

„A középkori Európa sárkányelképzeléseiben kétfajta sárkány élt: a többfejű sárkány, amely vizet őrzött, tüzet okádott, $s$ az embereket és állatokat egyaránt megtizedelte, valamint a repülő sárkány, amely vihart keltett, s a fellegekben lakott. Mindkét sárkánytípusnak több változata alakult ki. A repülő sárkány, mely elsősorban a hiedelemmondákban él, nyilvánvalóan ősibb típus a - főleg csak népmeséinkből ismert - többfejü sárkánnyal szemben." (Vargyas 1988)

\section{Hogyan lett gonosz a sárkány?}

A magyar néphit nem túl gazdag természetfeletti lényekben. A minket körülvevő, illetve nálunk kisebbségként élő népcsoportoktól sokkal több mitikus lényről szóló történetet gyűjtöttek össze, olykor három-négy különböző lény nevének mindössze egy magyar megfelelőt lehetett találni. Az Őrtilos-Szentmihályhegy környéki horvátok hiedelme szerint például a copernica (veštica) egy olyan boszorkány, aki élő személy, átváltozni nem tud, a démoni boszorkánynak pedig férfi (svečar/mrak) és női (susorka) alakja is van. Utóbbi lidérchez hasonló tulajdonságokkal is bír (Dömötör 1981). A magyar néphitben ezeknek az alakoknak nincsen konkrét megfelelője, csak a boszorkány (esetleg lidérc) szóval lehet körülírni őket. Az európai népek mitikus lényei általában ambivalensek, de tény, hogy jóval több pozitív szerepű természetfeletti lény található a többi európai nép hiedelmeinek sorában, mint a magyarokéban. Constantin Eretescu a román néphit természetfeletti lényeit négy csoportba sorolta a funkciójuk szerint: jóindulatú, rosszindulatú, jó- és rosszindulatú, valamint igazságosztó (Dömötör 1981). A magyar néphit esetében viszont nem lenne sok értelme hasonló csoportosításnak, mivel a mi misztikus lényeink általában félelmetesek, de legalábbis gyakran ambivalensek. Vannak ugyan ellenpéldák is, mint a ludvérc vagy a bolygó mérnök, melyek segítő démoni lények, de még ezek sem mentesek az ellentmondásoktól. A magyar nép a természetfeletti lényeket gyakran összefoglaló néven „rosszaknak”, „gonoszoknak” nevezi (ezek az év babonás napjain nem engedik, hogy az emberek bizonyos munkákat végezzenek).

Népi hitvilágunk misztikus teremtményei (például boszorkány, sárkány, kísértet, garabonciás stb.) tehát jellemzően negatív tartalommal vannak felruházva. A kérdés, hogy miért? A jelenség oka valószínűleg történeti: a keresztény vallás felvételét követően a magyarság addigi, pogány istenvilága, hitrendszere kicserélődött a keresztény hitvilággal. Márpedig a kereszténység fundamentumait tartalmazó Szentírás egyértelműen és kizárólag negatív kontextusban említi a sárkányt, gyakorlatilag a sátán jelképeként. Érdekes ugyanakkor, hogy a 13. századra már pápai címerállat is lehetett - akkor már az őrködés, éberség, éleslátás szimbólumaként (Vígh szerk. 2019).

A nép még jó ideig őrizte a pogányság képzeteit, de mivel a szomszédos, indoeurópai nemzetek nyelvük és mítoszaik szempontjából is nagyon különböztek, a régi magyar hit elemei lassan kikoptak (Dömötör 1981). Nagy Olga a jelenséget „isteni lények befeketítésének" nevezi, és a boszorkányok, valamint a sárkányok alakjának jelentésbeli változását említi példaként (Berze Nagy János nyomán; Nagy 1974). 
Nagy Olga az eltorzított sárkányalak ősi, isteni, nagylelkű (!) voltát számos példával igazolja (Nagy 1974). Ám, mivel ezek a „bizonyítékok” a legarchaikusabb meserétegek szintjén vannak elrejtve, lentebb, a népmesei sárkány jellemzésénél térünk ki rájuk.

\section{Népi képzetek}

A XIX-XX. századi népi elképzelések a sárkányt legfőképp a vizekkel, viharral, esővel hozták kapcsolatba. Egyes magyar területeken úgy gondolták, hogy a sárkány idézi elő a viharokat, más helyütt azt hitték, a zivatart okozó garabonciás legény használja a sárkányt hátaslovaként. Néhol úgy képzelték, hogy tengerekben, folyókban élnek, ahonnét felhő formájában viszik fel a vizet az égbe, a viharral szállítják vissza azt a földre, majd az égiháború után visszatérnek lakóhelyükre. Más országrészeken azt gondolták, hogy a mocsárban hét évig megbújva élő kígyóból keletkezik a sárkány, esetleg a vízben élő, tizenhárom éves harcsából (Dömötör 1981). Másutt az olvashatjuk, hogy olyan kígyóból vagy harácsból lesz sárkány, amelyet hét évig senki sem látott (Vígh szerk. 2019). A csallóközi, honti és kecskeméti néphagyományok szerint a sárkányok kutakban, barlangokban, tavakban vagy mocsarakban lakhatnak. A hal vagy a kígyó válhat sárkánnyá (különösen az a kígyó, amelyik maga is kígyót eszik) (Kandra 1897).

A sárkány és a víz kapcsolatáról alkotott magyar népi hiedelmek sokrétűek, olykor megfelelnek az ókor óta létező, általános európai képzetnek: a szörny nem engedi az embereket az életadó vízhez, csak abban az esetben, ha a közösség embert (lányt) áldoz neki (Dömötör 1981). Ez a motívum a magyar néphitben nagyon ritkán figyelhető meg (népmeséinkben viszont gyakran), de egy XIX. századi könyvben akad példa hasonló eset leírására. Egy meg nem nevezett magyar faluban történt néhány évvel azelőtt, ahogy a szerző lejegyezte az esetet, hogy nagy aszály sújtotta a települést. Az egyszerű helyi emberek azt hitték, hogy valamilyen túlvilági, gonosz erő tartja vissza az esőt, ezért egy lányt leeresztettek a kútba. Ezzel a babonás módszerrel akarták elérni, hogy eleredjen az eső. A lány viszont halálra rémült a kút mélyén, mert előzőleg azzal ijesztgették, hogy ott tanyázik a hétfejű sárkány, aki az összes esőt abba a kútba „húzta”. A lányt holtan emelték ki a mélyből, apja pedig a holttestet látva megőrült (Varga 1877). Ez a megtörtént eset azt is bizonyítja, hogy a mese és a hiedelem mennyire szoros kapcsolatban áll egymással.

Székelyföldön sárkánynak hívják az esőfelhőből leereszkedő esőfüggönyt. A népi képzet azonban nem csak az égzengéshez és az esőhöz rendeli hozzá sárkányt. Elődeink a jégesőt, a forgószelet, a szélvihart, az aszályt, a földrengést vagy bármilyen ijesztő természeti jelenséget az ő tevékenységének tudtak be. A Hajdúságban a futó széltölcsért sárkányfarknak nevezték; ha a szél feltépte a háztetők nádkévéit, azt mondták rá, hogy „Sárkány farka érte” (Solymossy 1931). A XVII. századi Cserei Mihály szemtanúként számol be egy esetről, amelyben valószínűleg egy sárkánynak vélt meteort pillantott meg: „Egy este felé Keczén az urral kün a kapunál állottunk sokan, s nagy hirtelenséggel az egén egy szárnyas sárkány szikrázva keresztülmene; más helyeken is az országban ugyanakkor láttatott." (Kazinczy 1852: 308)

Régen a mai Szlovákia területén lévő három községről úgy tartották, hogy a falvak alatt, a földben egy sárkány lapul: Újbeszterce alatt van a sárkány feje, Óbeszterce alatt a teste, Radoska alatt pedig a farka. Amikor ez a sárkány megmozdul, a vidéket árvíz borítja el (Kandra 1897).

Az ország egyes vidékein a kincsőrző szerepű sárkányba vetett hit is élénken élt. (Az őrzősárkány alakja egyébként a görög mitológiából származhat - Vígh, szerk. 2019.) Szücs Sándor 1940-ben lejegyezte, hogy Sárréten a sárkányt már nem említik gyakran a hiedelmekben, viszont a XIX. században még mutogattak sárkánylyukakat, amelyekben a 
sárkánykígyó lakik. Bizonyos helyeken azt is megjegyezték, hogy kincset őriz, amelyet csak a táltosok vagy a garabonciások tudnak tőle elvenni. Az egyik leghíresebb, tréfás történet a „csökmői sárkány” históriája, amely azt bizonyítja, hogy Hajdú-Biharban a XVIII. században még mennyire hittek a kincsőrző sárkányban. A történet lényege, hogy Csuba Ferenc sárréti táltost, „tudományost” többször is letartóztatták varázslótevékenysége miatt, erre az illető becsapta az őt elfogni szándékozó személyeket azzal, hogy meg tudja szerezni a csökmői sárkány kincsét (Dömötör 1981). Ebben a példában az a régi elképzelés is megbújik, mely szerint a félelmetes sárkányt csak egy különleges képességekkel rendelkező ember közelítheti meg. A hiedelmeinkben a táltos az a személy, aki megküzd a sárkánnyal (a népmeséinkben a hős legény párbajozik vele).

Egy másik magyar hiedelem a sárkányt a táltos lóval hozza kapcsolatba: a táltos lovak nem pusztulnak el, hanem a felhőkbe mennek, onnét árvizet küldenek, sárkányokká válnak (Nagy 1974).

A magyar nyelv a sárkányt néhol sárkánykígyó elnevezéssel is jelöli, tehát a magyar népi kultúrában is megfigyelhető a két alak összemosódása. A bodrogközi történetekben például „tarajos kígyó” szerepel, amely „boszorkányos féle kígyó”. Ha utoléri az embert, akkor agyonüti (Dömötör 1981). Ehhez a kígyószerű alakhoz nagyon hasonlít a Varga János leírásában szereplő sárkány: „A sárkányt egy nagy kigyónak képzeli a nép, melynek taraja, négy lába, két szárnya s rémítő nagy szája van." (Varga 1877, 83)

Egy XVII. század végi könyvben „tsúszó-mászó” állatok címszó alatt a sárkányok két fajtáját különítik el. Az egyik félének két, hosszú, vékony hártyából álló szárny emelkedik ki a hátából, a másik fajtájú sárkányoknak viszont nincsen szárnyuk, hanem ezek hatalmasra megnőtt, nagyon öreg kígyók (Solymossy 1931). Egy 1949-es erdélyi, széki helynevekkel kapcsolatos gyűjtésben Filep János adatközlő arról számol be, hogy a sárkány a gyíkhoz hasonlít. A székiek Sárkánytónak hívtak egy dűlőrészt, amely akkor már mocsaras, nádas vidék volt, de a helyiek emlékezete szerint régen egy tó volt ott. Azon a helyen „tisztátalan” dolgok történtek, például emberek tűntek el titokzatos körülmények között. Úgy tartották, hogy a tóhoz mindennap sárkányok jártak le a Sárkánytetőről, hogy igyanak. Utóbbi hely egy dombos vidék, sok-sok gödörrel. E gödrökről azt gondolták, hogy a sárkányok ott bújnak elő a földből. Minden hat év után végleg előbújnak, aztán felszállnak az égbe, ahonnan jégeső formájában hullanak a földekre (Nagy 1974).

A nógrádi néphit szerint a sárkányok nagy ellensége a „barbonczás” (garabonciás). A barbonczások a sárkányok felett hatalommal bíró és egyéb különleges képességekkel is rendelkező emberek. Tizenketten vannak testvérek, és a felhők között laknak. Az évnek csak bizonyos napjain jönnek le a földre, hogy a sárkányokon lovagoljanak, illetve azokat begyűjtsék. A sárkány csak akkor jön elő rejtekhelyéről, amikor a garabonciás „kiimádkozza" onnét. (Titkos könyvéből olvas rá az állatra, amelyből csak ő tud olvasni.) A megbűvölt sárkányt megnyergeli, villámsebességgel megy rajta „szerecsen országba”. Ott levágja, húsát pedig nagyon drágán eladja a szerecseneknek, akik az iszonyú forróságot csak úgy tudják kibírni, ha a nyelvük alatt tartanak egy darabka sárkányhúst (mivel az jéghideg). (A garabonciás rengeteg arannyal, drágakővel tér vissza onnan - Kandra 1897.)

Összességében megfigyelhető, hogy a magyar néphitben kétféle sárkányalak fordul elő. Az egyik a tarajos kígyó, amely természetfeletti erővel rendelkező állat, a másik a garabonciás „hátasa”, aki az időjárást befolyásolja (Boldizsár 1997). (A vízőrző és a kincsőrző sárkányokba vetett hit csak ritkán figyelhető meg.) Érdekes, hogy a magyar néphit sárkánya általában egy fejjel és szörnyszerű (állati) külsővel rendelkezik (egy fejjel jelenik meg a Gonoszt jelképeként, vallásos ábrázolásokon is), ellenben népmesé- 
ink sárkányai leggyakrabban többfejűek, és nem ritkán emberi módon élnek (Dömötör 1981).

Más nézet szerint a hazai folklórban nem kettő, hanem négyféle sárkányt találhatunk:

1. A 'zomok', amely egy kígyószerű mitikus lény, sárkánykígyónak is hívják. Ennek altípusa a 'mocsári sárkány', amely csak a lakhelyében különbözik, de ugyanúgy emberekre vadászik, és rettegnek tőle.

2. A sárkánykígyó a zomokból keletkezik, s valójában a garabonciás hátaslova.

3. A 'többfejű sárkány' tipikusan mesei alak, hiszen a mondákban inkább egyfejűvel találkozunk. A többfejűnek van alvilági és felvilági változata is, illetve idetartoznak az 'égitestrablók' is. A „többfejű sárkány” a magyar nyelvterületen kicsit átalakult, külseje alapján szörny, tulajdonságai, céljai alapján inkább emberszerű figura rajzolódik ki a történetekből.

4. Ember alakú sárkánnyal elsősorban az észak-magyarországi mesekincsben találkozunk. Ezek minden szempontból antropomorfak (Vargyas 1988).

\section{A sárkány szerepe a népmesében}

A nép ősidők óta őrzi azt a meggyőződését, hogy a világ az állandó küzdelem színtere. A pozitív és negatív erők harcának szemlélete abból az ősi tapasztalásból ered, hogy a természetben minden küzdelem árán születik és fejlődik. A mesékben pedig a nép legmélyebb világszemlélete tükröződik, így a népmese, különösen a tündérmese a hős küzdelmének története, erejének és emberségének próbája.

Ebben a küzdelemben a mesehős testesíti meg a jót, a pozitív erőt, a sárkány pedig a negatív erők szerepében lép színre. Ahogy az ősi világfelfogás a jót és rosszat egyaránt létfontosságúnak tekinti, a mesében is a sárkány jelenléte éppúgy szükségszerű és elengedhetetlen, akár a hősé. A sárkány hiányában a hős nem is lehetne igazi hős, hiszen nem tudná kin lemérni erejét. A hős és a sárkány küzdelme tehát sorsszerű. A megmérkőzés sorsszerűsége a népmesékben talán akkor mutatkozik meg legnyilvánvalóbban, mikor a sárkány a nevén szólítja a hőst, illetve kijelenti, hogy már akkor tudta, hogy egy nap el fog jönni őt elpusztítani, amikor az még meg sem született (Nagy 1974).

A hős mitikus erővel és egyéb különleges képességekkel megáldott személy, így ellenfele sem lehet kisszerü, gyenge vagy együgyü. Hiszen, ha a küzdőtárs nem lenne méltó a hőshöz, akkor utóbbi érdeme csekély lenne. „Az ellenfél tulajdonságai nem állhatnak oppozícióban a hőséivel; a bátor, erős, okos hős csakis bátor, erős, okos ellenféllel mérkőzhet meg, vagy pedig olyan természetfölötti lénnyel, akinek ereje (személyiségének titka) rajta kívül, ismeretlen helyen van." (Boldizsár 1997, 54-55) Az erőviszonyok így lesznek kiegyenlítettek. A hősnek azonban mégis felül kell kerekednie, ezért különféle segítőtársak szegődnek mellé, hogy a mérleg végül az ő javára billenjen (Boldizsár 1997).

Ritkán, de előfordul néhány magyar népmesében, hogy a sárkány átveszi például a hőst segítő állatok szerepét, ilyenkor segítő-tanácsadó funkciójú lényként szerepel a mesében, illetve adományozóként is megjelenhet. Ezeket a kivételes eseteket leszámítva a sárkány mint legyőzendő fél, küzdőtárs van jelen a népmesében. Bár az örök konfliktust jelképezi, ha abból a szempontból közelítünk felé, hogy a világot mindig a küzdés mozdítja előre, akkor talán már nem is tűnik annyira gonosznak, rettenetesnek.

A sárkányról a magyar népmesékben általában először a fejei száma derül ki. Ez legtöbbször három, kilenc vagy tizenkettő, esetleg hét, de gyakrabban a három többszöröse. A népmesei sárkányról kialakult általános képzetünkhöz a sokfejűségen kívül a hatalmas test, a tűzokádás képesség, a repülni és átváltozni tudás is hozzátartozhat. A mesék szövege ugyanakkor legtöbbször nem árul el semmi egyebet a kinézettel kapcsolatban. A 
sárkány alakja három létező állatfaj kombinációjából jöhetett létre: a halak (nagyobb testűek), a gyíkfélék (aligátor, krokodil) és a kígyó alakjából (Róheim 1911). Solymossy Sándor szerint a sárkány hatalmas termetű, teste gyíkhoz hasonló és kemény pikkelyekkel borított, négy erős, de rövid lába van, ezen kívül bőrszárnyai, ragadozó karmai, tüsketarajos nyaka, ezen pedig vagy krokodilszerű, vagy kígyófej található (Solymossy 1931).

A népmesei sárkány magában hordozza a néphit sárkányának jellemvonásait, de nem akként van jelen a mesében, hanem rettentő erejű, mitikus ellenfélként. Élhet földön, mocsárban, hegyekben, barlangokban, vízben, a föld alatti másvilágban és a felhők felett is. Lehet vízi szörnyeteg, amely leányt (áldozatot) követel, lehet kincsőrző, égitestrabló, de lehet a hős segítőtársa is, és élhet akár szerető férjként is (Boldizsár 1997).

\section{Az isteni eredet nyomai}

Nagy Olga írja (Berze Nagy János nyomán), hogy az égitest-szabadító mesetípusban egy egész „sárkánynemzetség” van jelen (Nagy 1974). Az ehhez a csoporthoz tartozó mesék réges-régről, Keletről eredeztethetők, és az anyaistennő-hit, valamint a planétaisten-hit egybeolvadásából keletkeztek. Ezek a mesék a mai napig elevenen, mitikus hősi eposzként hatnak. E típus meséiben az alvilág férfi és női istenalakjaival találkozunk. Az alvilág „feje” a sárkányok anyja (ebben is megnyilvánul az anyaistennő-hit), „segédei” a három sárkányfiú, illetve ezek három felesége, ők együtt pontosan heten vannak, akár a planétaistenek (Nagy 1974).

A sárkány mitikus, isteni eredete megőrződött ezekben a népmesékben. A sokfejűség például ennek egyik jellegzetes nyoma. Emellett a sárkány földi leányokat rabol, ahogy a görög istenek is földi asszonyokkal háltak.

Az életmódja és táplálkozása is mitikus jellegű. Pompás kastélyban él, amely valamilyen madárlábon forog, és csak a beavatottak tudják megállítani azt. A germán istenekhez hasonlóan hatalmas termetű és ebből adódóan nagyétkű is: egy evésre több ökröt, több kenyeret és egy hordó bort fogyaszt el.

Az ereje is félelmetes, isteni: többmázsás buzogányát sok mérföldről hajítja haza úgy, hogy az betöri a kaput.

A sárkánynak olyan eszközök vannak birtokában, melyekkel az egyszerű földi halandók nem rendelkeznek. A kardját a hősön kívül más nem tudja kezébe venni, használni, vagy lehet olyan kardja is, amely magától vív. Ilyen kard pedig nem jár ki akárkinek, csakis isteni eredetű lények rendelkezhetnek hasonlóval. A csodás eszközök között szerepel a sárkány selyemingje is, amely viselőjének erejét megsokszorozza.

A sárkány lova sem akármilyen lény, hanem táltos paripa, amelynek gyakran négynél több lába van (vagy éppen három), melyekkel olyan sebességgel száguld, mint a gondolat. Egyedül a hős birtokában lévő táltos haladja meg képességeit.

Ezek fényében érzékelhető, hogy a sárkány nem a borzalmat testesíti meg (mint például a boszorkány), hanem sokkal inkább a „grandiózumot”, mely nem hiányozhat egy tündérmeséből (Nagy 1974).

\section{A nagylelkú ellenfél}

Ahogy a sárkány isteni eredetét is már csak néhány elem bizonyítja, úgy az istenségével együtt járó nagyvonalú, kegyes természetét igazoló nyomokat is már csak a legősibb mesevariánsok tartalmazzák.

Ezek szövegéből olykor kiderül, hogy a sárkány szerelemmel szereti az elrabolt királylányt, gyöngéden viszonyul hozzá. Az „elrejtett erő” típusú mesékben a királykisaszszony, aki a hőst szereti, éppen a sárkány bizalmát játssza ki, amikor megtudakolja, hogy 
miben rejlik az ereje. A sárkány felesége kérdései hallatán először még gyanakszik, nem mondja meg neki rögtön a legféltettebb titkát, azonban a nő szerelmet színlelve meglágyítja a szívét, így végül elárulja az igazat. A különféle változatok gyakran érzékeltetik a sárkány örömét, amikor a királylány kifejezi iránta érzett szerelmét, szeretetét.

Ugyancsak a sárkány nagylelkűségét igazolja az a jelenség, amikor a hős megérkezik az alvilág urának kastélyába. A sárkány tisztában van azzal, hogy miért jött a hős, és már azt is tudja, hogy egy vagy két fivérét az ifjú nem sokkal azelőtt megölte, ennek ellenére sosem támadja hátba, nem rohanja le és végzi ki. Épp ellenkezőleg: vendégül látja, étellel-itallal kínálja, majd vitézi küzdelemre, erőpróbára hívja a hőst. Olykor még a választás lehetőségét is megadja a hősnek, hogy milyen módon szeretne megmérkőzni (karddal vagy birkózással). A küzdelem nyílt, az ellenfelek egyforma ereje miatt több összeütközés után is döntetlen marad. Néhány variánsban megfigyelhető, hogy a harc során végül a hős valamilyen ravaszsággal, csellel győzedelmeskedik a sárkány felett.

Mérai cigánymesékben találhatók még érdekes elemek a sárkány jellemére vonatkozóan. Egy mesében a sárkány bakkecske képét magára öltő ördöggel verekszik, de sehogy sem tudja legyőzni azt. A közben megérkező hőstől mindkét fél segítséget kér, a hős viszont a sárkány mellé áll. Ebben a mesében tehát a sárkány egyértelműen pozitívabb jelentést kap, mint az ördög. Hálából a sárkány megajándékozza a hőst egy olyan sállal, amely a földhöz verve kígyóvá vagy csodaszép leánnyá változik (Nagy 1974).

Talán az sem véletlen, hogy a sárkányok néhány mesében a hős segítőjeként szerepelnek, például a hős sógorai, akik tanáccsal vagy különféle adományokkal látják el a főszereplőt (Boldizsár 1997).

\section{Kutatásunk eredménye}

Kutatásunk során nyolc magyar népmesegyűjteményt (lásd a bevezetőnél) tekintettünk át, melyekből csak a sárkányos népmeséket vizsgáltuk meg alaposabban.

A nyolc gyűjteményben összesen közel száz olyan népmesét találtunk, amelyben szerepelt a 'sárkány' (helyenként 'sárkán' alakban) szó. Ebből néhány mesében a sárkány nem a történet szereplőjeként volt jelen, hanem csupán egy-egy említés erejéig (például „sárkánytejet szopott”). Ezért ezeket a meséket tanulmányunk szempontjából nem tartottuk relevánsnak.

Az így maradt mesékben megvizsgáltuk a bennük szereplő sárkányok alakját és életmódját, és eszerint a sárkányos népmesék négy csoportját különítettük el. Az állatszerü szörny csoportba azokat a népmeséket soroltuk, amelyekben a sárkányok fenevad alakjához nem fér kétség: tűzokádók, emberáldozatot követelők, tavak, kutak lakói vagy a néphit kígyószerű szörnyetegeinek népmesei megfelelői. Az antropomorf sárkány egységhez azok a népmesék tartoznak, amelyek sárkányai emberi életformát folytatnak (például kastélyban vagy házban élnek, földi nő a feleségük), emberi vagy emberszerü külsővel rendelkeznek (legalábbis nem kapunk ezzel ellentétes információkat a szövegből), emberi tevékenységeket végeznek (például lovagolnak). A harmadik csoportot azok a népmesék képezik, amelyekben egy-egy mesén belül összekeveredett a szörnyszerű és az antropomorf sárkány alakja. Külön csoportba tettük azokat a meséket, amelyeknél nem lehetett egyértelműen eldönteni a sárkány attribútumait.

Fontos megjegyeznünk, hogy a sárkány fejeinek száma nem határozza meg annak ember- vagy szörnyszerű alakját, mivel ezek a számok a mesemondó (-gyűjtő...) tetszése szerint változhatnak. Tehát a hét-, kilenc-, huszonegy fejű sárkány is lehet antropomorf, ha emberi módon él. Hasonló a helyzet a beszéd képességével. Az állatszerű sárkány is beszélhet, megfenyegetheti a mesehőst, a várost, amelytől megvonja a vizet, de ettől még emberevő szörnyetegként él. 


\section{Az állatszerü szörny}

$A$ vadász királyfiakban a három fivér az apjuk által megtiltott fekete havasba megy vadászni. Ott aztán minden éjfélkor egy háromfejü, egy öt-, és egy hétfejü, tűzokádó sárkány jár a rézvályúra inni, akik a fekete gyász városa melletti fekete tóban laknak. A város nagy ellenségként tekint rájuk. Akiket éjfélkor az ivóhelyük közelében találnak, legyen az állat vagy ember, azonnal megölik. A királyfiakat is fel akarják falni, de azoknak sikerül elpusztítani a szörnyeket, melyekből annyi vér ömlik ki, hogy eloltja az őrtüzet (Kriza 1863). A sárkányokról keveset tudunk, emberszerű cselekedetük nincs.

Az Igazság és Hamisság című besenyőteleki mesében a tűzokádó sárkány a kútban lakik, és a vizet meglehetősen drágán adja: egy korsónyiért egy asszony vagy egy leány életét kéri (Berze 1907). Nem lényegtelen megjegyeznünk, hogy ugyanennek a mesének a Kriza-féle változatában (Az Igazság és Hamisság utazása címmel) nincs sárkány, ott a kutat kő zárja el, amelyet egy ördög helyezett oda. Ugyanezt találjuk a Benedek Elek-féle verzióban (Igazság és Hamisság).

A klasszikus, vízmegvonó, emberáldozatot követelő sárkány figyelhető meg A pásztorfiú viaskodásai és a Leányt evő Sárkány című népmesékben is. A rettenetes szörnyeteg a város egyetlen kútját foglalta el, és a királylányon kívül már minden hajadont megevett (Ipolyi 1914).

A csodaszörny című népmesében (amely a Szépség és a Szörnyeteg magyar megfelelője), amikor a leány apja az elvarázsolt tündérkirály kertjéhez ér, a kapuban két hatalmas sárkánykígyó áll őrt (kővé dermedve) (Merényi 1861).

A nádszál kisasszonyban szintén őr szerepében jelenik meg a fenevad. Amikor a királyfi egy nagy vaskapuhoz érkezik, ott egy „ebadta” százfejű sárkányt talál, aki senkit sem enged bemenni. A hős azonban a varázsfurulyáján olyan szép dallamot játszik, hogy „...még az a nagy erős állat, maga a százfejű sárkány is megjuhászodott: veres taréja lekonyulván, borzas pikkelyei szépen egymásra lapultak. Lehentergett aztán a földre, s ott szúkölt, ott vajudott mint a kutya, mikor gazdáját ismét láthatja." (Merényi 1861: 45-46) Ezek után már nem okoz gondot a hősnek a bejutás, egyszerűen keresztülsétál a fekvő sárkányon, ami eközben a farkát csóválja, és a királyfi lábát nyalogatja (Merényi 1861).

Merényi László Eredeti népmesék című gyűjteményében A Vízi Péter és Vízi Pál című mesében (Merényi 1861) rögtön jól kirajzolódik az (ős)hüllőre hasonlító, fenevadként élő szörny alakja. Vízi Péter útja során egy városba ér, amely feketével van bevonva. Egy özvegyasszonytól megtudja, hogy huszonnégy esztendeje egy óriási sárkány repült el a város kútja felett, és a tojását abba belehullajtotta. A tojásból egy tizenkét fejű sárkány kelt ki, aki kisajátította a kutat, és minden évben egy tizennyolc éves leányt követelt áldozatul, különben egy csepp vizet sem ad az embereknek. Vízi Péter megküzdött a sárkánnyal, aki vörös, kék, zöld lángokat okádott már a kút mélyéről, majd kiugrott onnét, és akkorát fújt, ami egy vitorláshajót is felborított volna. A sárkány a „pikkelyespánczélos" farkával agyon akarta ütni a hőst. A hosszú küzdelemben végül a vitéz a sárkány száját kipeckelte buzogányával, bemászott a szörny fekete galamb formájú lelkéhez, azt leszúrta, s így vetett véget az életének. Utána Péter a sárkány összes fejéből egyegy aranyalmát szedett ki, majd a fenevad oldalát felvágva jutott ki belőle. Később a sárkány aranyfogait is kiszedi, amelyeket a történet végén a felszántott földbe elültet. Azok kihajtanak, és gyönyörű hajadonok fejlődnek ki belőlük, akiknek viszont nagyon haragos, zsémbes természetük lesz. (Régen úgy hitték, a rossz természetű asszonyok sárkányfogból származnak. Lásd: Merényi 1861.)

Néhány esetben megfigyelhető a magyar néphit sárkányának (a garabonciás sárkányának, illetve a tarajos kígyónak) „beszivárgása” a népmesékbe. A mesékből is egyér- 
telműen látszik ennek a sárkánynak szörnyszerű alakja, ezért ehhez a típushoz soroljuk a következő néhány példát.

A Garabonczás és a Sárkányok-ban a juhász észreveszi, hogy a juhok titokzatos módon a tóba vesznek, valamilyen lény olyan gyorsasággal ragadja magával őket, hogy nem is lehet látni, mi lehet az. A juhász gyermekkorában hallotta, hogy a Sárkány is pusztíthatja a nyájat, sőt később az ember ellen fordulhat, mert az emberhúst is megeszi. (Ipolyi gyűjteményében a sárkány szó mindig nagy kezdőbetűvel szerepel.) Végül egy „Öreg rongyos" (Garabonczás) jóvoltából fény derül a titokra: az Anyasárkány él a tó mélyén hét fiatal fajtársával. A Garabonczás felkantároz két Sárkányt, azokra felülnek a juhászszal, felszállnak a magasba, és úgy repülnek, mint a szélvész. Ha jó emberek felett szállnak el, akkor csendes időt idéznek elő, ha rossz emberek felett, akkor pedig szélvészt keltenek. Végül olyan „népfaj” közé érkeznek, amely nagyon közel lakik a Naphoz. Hogy kibírják az olvasztó meleget, Sárkányhúst hordanak a hónuk vagy nyelvük alatt, mivel az jéghideg. A Garabonczás megöli a sárkányokat, és azok minden falatját aranyért adja el az ottaniaknak (Ipolyi 1914).

A Ráadó és Anyicska című mesében a gonosz királyné üldözőbe veszi a két hőst. Mikor azokat sem lapáton, sem pemetén, sem gereblyén ülve nem tudja utolérni, „megnyergel” egy sárkányt (akár az előbbi garabonciás), s így a szélnél is sebesebben száguld utánuk (Arany 1862). A király és az ördög című népmesében az ördög és annak felesége szintén két „megnyergelt” sárkányon „futnak” a szerelmespár nyomában (Erdélyi 1848).

$A z$ ecsedi Sárkányban is a néphit és a népmese keveredése figyelhető meg. A mese szerint századokkal ezelőtt élt az ecsedi lápban egy Sárkány. A fenevad a vidék barmait dézsmálta, iszonyatos ordítása megrengette a földet. A vele szembeszálló hős kardja csak úgy szikrázott a Sárkány pikkelyein. A küzdelem után a „kígyó” végignyúlott a földön, és mérges nyelvét öltögette ellenfelére (Ipolyi 1914).

A tátos című mese a vízmegvonó sárkány klasszikus történetével indul: a tűzokádó minden nap egy lányt fogyaszt el. Amikor már az összes lányt megette, azzal fenyegeti meg a várost, hogy minden vizet felszív. A király a lányait nem akarja odaadni, azonban mégis kénytelen, miután a Sárkány valóban eltűnteti a vizet az utolsó cseppig, és tetejébe még a Napot, a Holdat és a csillagokat is felfalja. A főhős viszonylag könnyen legyőzi a tizenkét fejűt, akinek nem ismerjük meg emberszerű tulajdonságát, viszont tüzet fúj. Később feltűnik a 'Vasorrúbába', akit először a Sárkány feleségeként említ a szöveg, nem sokkal lejjebb már az anyjaként (Ipolyi 1914).

Egy hasonló mesében (A talált gyermek) a hétfejű Sárkány egy szirtbarlangban lévő vízben él, szintén naponta egy lányt fogyaszt el. Külsejéről, sajátosságairól keveset tudunk meg: hétfejü, s a leányokat megeszi. Az anyja egy boszorkány („Öregasszony”), aki - miután a Sárkányt a hős megölte - fia csontjait vasfazékban főzögeti, hogy az felelevenedjék (Ipolyi 1914).

Egy másikban (A két testvér) a rettentő tizenkét fejű („rút állat”) a tengerből veti ki magát, később annak apja is előbukkan a vízből. A hős a parton végez mindkettővel. A Vénasszony nem sokkal később ott szedegeti az állatok csontjait. Lejjebb kiderül, hogy a szörnyek a fiai voltak (Ipolyi 1914). Azzal együtt, hogy e mesékben hús-vér ember a sárkány anyja, attribútumai alapján inkább állatok a sárkányok.

Az ősi keleti kultúrkörben a „Sárkányok anyja” az úgynevezett anyamítosz istennőjének számított. (Ez az anyaistennő-hit egészen az ősi, matriarchális társadalmakig nyúlik vissza.) Az új, keresztény vallás formálta át alakját alvilági „Vasorrú bábává”. Ugyanígy a sárkányok is az ősi, úgynevezett planétamítosz (égitesteket istenként tisztelő vallás) istenségei voltak, a fenti világ harmadik régiójában laktak, később az anyaistennővel együtt a népi tudatban a pokol lényeivé süllyedtek le. Tehát a kereszténység térhódítása 
volt az oka annak, hogy a pogány motívumok az ősi jelentésükkel éppen ellentétes, eltorzult tartalmat kaptak. „Köztudott dolog, hogy az újabb mítosz nevében a régi mítoszkörből való elemek »befeketítődnek «." (Nagy 1974: 106) A természetfeletti lényekhez hasonlóan az ősi vallás „szent” elemei (például tánc, varázslat, rituálék, szépség és gyönyör) szintén kárhozatos, tiltott dolgoknak számítottak a kereszténységben.

A három fiú című mesében sok korábban ismert történet motívumai feltűnnek. Először a vízmegvonó Sárkány tűnik fel, amely már tizenegy, vele szembeszálló vitézt is elfogyasztott, másnap pedig a király leányát szándékozik megenni. A mese egy későbbi pontján tizenkét fejű Sárkányt is említ, amely ezer éve él egy istállóban, és széttépi azokat, akik arra tévednek. (A Vénbanya azt a feladatot adja a hősnek, hogy ölje meg a Sárkányt, a vérével és ganajával trágyázza meg a földet, a nyelvét és máját pedig hozza el a lányainak (pecsenyének).) A szövegben lejjebb már egy huszonnégy fejü Sárkány barlangjában zajlanak az események. Onnét kiérve a hős egy aranyvárban huszonnégy lakat alatt egy királylányt talál, akit a Sárkány vitt oda (kinek pincéjében arany, ezüst és embervér van) (Ipolyi 1914).

Összességében megállapítható, hogy ezekben a történetekben a sárkány többnyire olyan szörnyeteg, amely helyettesíthető lenne óriással, farkassal vagy más szörnnyel, amely inkább állati attribútumokkal bír. (Ilyen helyettesítésre láttunk is példát.) Másutt pedig egyfajta táltosként paripaként használják a hősök. E lények szerepe a történetekben tehát a legyőzendő, félelmetes ellenség/szigorú, veszélyes őr szerepének betöltése, illetve lovat helyettesítő segítő.

Lányrabló, amúgy állati tulajdonságokkal rendelkező sárkányra nem láttunk példát, amikor lányt követelt a fenevad, azokat felfalta, vagy megpróbálta felfalni.

\section{Az antropomorf sárkány}

A legarchaikusabb meseréteghez tartozó Fehérlófiában a sárkányok az alvilág urai. Bár termetük és erejük hatalmas, emberi (emberszerű) mivoltukhoz nem fér kétség. A három sárkányfivér földi királylányokat rabolt feleségnek, azokkal három várban élnek a lenti világban. A legidősebb királylány férje, a háromfejű, amikor hazaérve megpillantja Fehérlófiát, küzdelemre hívja (nem ront rá rögtön). A hős úgy vet véget a sárkány életének, hogy földhöz vágja, fejeit pedig levágja. A középső királylány ura a hatfejű sárkány, aki azonnal megismeri a hőst. Már tudja azt is, hogy Fehérlófia ölte meg öccsét, azonban mégsem rohanja le az ifjút, hanem birkózni hívja. A legkisebb királylány elrablója a tizenkét fejű sárkány, aki „tizenkét mértföldről” belevágja buzogányát a várkapuba. A hős és a sárkány úgy küzdenek meg, hogy közben egymást deréknál fogva a földbe vágják (Arany 1862).

A Fehérlófia egy másik változatában a hőst Juhász Palkónak hívják, mivel egy juhász talált rá a mezőn (az előbbi változat fehér lova helyett ebben egy öreg anyajuh szoptatja tizennégy évig). Palkó első ellenfele, a hatfejű sárkány, a küzdelmük előtt „kőgölődények”-et eszik egy kis erősítő gyanánt, és ad belőle Palkónak is. A hős átkarolja ellenfelét, és fejjel lefelé a földbe vágja. A királylány könnybe lábadt szemmel hálálkodik a legénynek, amiért az megmentette őt „csúf kinzójától”. A középső királylány még segít is Palkónak, hogy biztosan legyőzze tizenkét fejű férjét: olyan selyeminget ad neki, amelytől ereje megkétszereződik. A harc előtt Palkó megebédel ellenfelével. Ebben a változatban a legkisebb leány férje, a borzasztó tizennyolc fejű sárkány a Fehérlófia című változatból ismert Kapanyányimonyók alakját is magába olvasztja: a mese szerint ugyanis ez a sárkány a fenti világban hegyes szakállú törpe alakjában mutatkozik. A leány odaadja az ifjúnak a sárkány selyemingjét (!), amelytől tízszer olyan erőssé teszi viselőjét, illetve olyan borral kínálja, amely szintén tízszeresére növeli erejét. A maradék 
bort a királylány kiönti, hogy férje ne ihasson belőle. A sárkány hazaérve rögvest átmegy abba a szobába, ahol erőt adó ingjét és borát tartja, s amikor nem találja azokat, idegesen futkos fel-alá (Erdélyi 1848).

Szintén a Fehérlófia egyik változata a Besenyőteleken gyűjtött Este, Éjfél, meg Hajnal című népmese. A három fivér, Este, Éjfél, Hajnal (nevüket arról a napszakról kapták, amikor születtek) elindulnak a három elrabolt királyleány keresésére, végül Hajnalt eresztik le kötélen az alsó világba. A kilencfejű, majd később a tizenkét fejű sárkány lépteinek dübörgését már messziről lehet hallani, buzogányukat pedig száz mérföldről hajítják haza. Hazaérve rögtön megérzik az idegen szagát, a feleségük pedig azt mondja neki, hogy a sógoruk jött el hozzájuk. A birkózás előtt ólomgaluskát és kőkenyeret esznek, utóbbit fakéssel vágják el. A tizennyolc fejű sárkány buzogányát olyan erővel hajítja haza, hogy az földet érve egy házhelynyi földet repít a magasba. A küzdelem előtt teleeszik magukat, aztán megbirkóznak egymással. Amikor a sárkány már nagyon elfáradt, a feleségétől kér egy pohár vizet. Az asszony úgy nyújtja oda a vizet, hogy Hajnal kaphassa meg, így végül ő kerekedik felül. (Mindhárom királylány a mesehősnek segít: olyan gyürüt adnak neki, amelyet, ha elfordít az ujján, hétszer erősebb lesz.) Ebben a mesében szerepel még egy huszonnégy fejű sárkány is, aki kivette egy öregasszony és egy öregember szemeit, mert azok az ő területére hajtották a juhaikat (a szemeket egy fa tetejére rejtette el egy cserépedényben). A mesehős természetesen elbánik ezzel is, az öregek szemét pedig visszaszerzi (Berze 1907).

A Hajnalka című népmese az előbbinek egy olyan változata, amelyben a hős nem az alvilágba indul az elrabolt leányok után, hanem éppen az ellenkező irányba. Hajnalka egy hatalmas vasmacskát készíttet vaslánccal, azt hajítja fel az égbe, a láncon pedig felmászik a fenti világba. Ott a három királylány azzal fogadja a hőst, hogy Sárkány-uruk mindig mondta nekik, hogy egyszer Hajnalka fogja megszabadítani őket. A hétfejű a buzogányát hazahajítja, rajta egy nyúllal. A feleségének a nyúl felét meg kell sütnie, másik felét meg kell főznie a Sárkány számára (a két bátyja őzet és szarvast hajít haza). A mesében egy rövid ,jelenet” erejéig feltűnik a legkisebb királylány másvilági menyasszonyi ruhája, amelyben hozzáment a huszonnégy fejü Sárkányhoz (Ipolyi 1914).

A Fehérlófia Ipolyi Arnold népmesegyűjteményében Csonkatehén fija címmel szerepel (a hős anyja egy Csonkatehén nevü asszony). Az ifjú először a kétfejü, majd a hatfejű, végül a tizenkét fejü Sárkánnyal küzd meg, akik a megszokott módon hajítják haza buzogányukat, majd a birkózás előtt kőpogácsát falatoznak a hőssel. Egy másik variánsban, a Medve Jankóban pedig a fenti világ királyának három leányát a tizenkét fejű Sárkány rabolta el, aki a másvilágon nem kastélyban, hanem csupán egy szép házban él velük. Az Erős Jancsi és a Hüvej-piczi népmesék szintén a Fehérlófia variánsai (Ipolyi 1914).

A feneketlen kút címü besenyőteleki mese is az eddig leírtak „rokona”. A legkisebb királyfi egy éjszaka észreveszi, hogy egy nagy bika lopja el a gyönyörü körtefa gyümölcsét. Az ifjú meglövi a bikát, de az elmenekül, a királyfi ezért két bátyjával együtt a keresésére indul. Egy nagy kút körül vérnyomot találnak, ezért a legkisebb leereszkedik a mélyére, így kerül az alvilágba. Ott betér először egy libalábon, majd kacsa-, végül pulykalábon forgó kastélyba, amelyekben királylányok élnek sárkány férjükkel. A sárkányok hazaérve azonnal megérzik az „idegenbűzt”. A hatfejű enni kér feleségétől, majd birkózni hívja a mesehőst, aki azonban úgy elkapja a sárkányt, hogy az rögtön „megdöglik”. A kilencfejű sárkány hazafelé jövet akkorákat dobbant a lábával, hogy a vár alapja is megremeg tőle, de a hős könnyen elpusztítja azt is. A tizenkét fejű már távollétében megérzi, hogy valaki jár a házában. A kapu előtt akkorát ordít, mint egy oroszlán, és belépve megszidja a feleségét, amiért egy idegent beengedett. Hét mázsa szurok elfogyasztása után „összeölelkeznek" a hőssel, aki végül megfojtja a sárkányt. Az ifjúnak még ezzel sem ért véget a 
feladata, mert előbb még meg kellett ölnie a sárkányok apját, aki bika képében már találkozott a hőssel. A vén sárkány egy nagy házban aludt az ágyában, fejénél és lábánál is egy-egy üveg pálinka volt, annak felesége pedig egy fekete kecske képében próbálta meg később a királyfit becsapni (Berze 1907).

$A$ tetejetlen fa című besenyőteleki mesében a hős négy hétig mászik egy aranycseresznyefán, míg eljut a fenti világba. Ott egybekelnek egy szépséges királylánnyal. Amikor felesége sétálni megy, a kastély kulcsait férjére bízza, meghagyva neki, hogy a tizenkettedik szobát ki ne nyissa, különben vége az életüknek. A hős mégis kinyitja, és egy sárkányt talál ott, aki egy asztalhoz van kötözve három abronccsal. A sárkány megkéri, hogy itassa meg borral (pohárból). A bortól aztán erőre kap, kiszabadul (a hősnek két életet ígér jutalmul a segítségéért), az ölébe veszi a királykisasszonyt, és magával viszi a kastélyába. A hős háromszor is megpróbálja visszaszerezni elrabolt feleségét, de a sárkány „tátos” lova hátán mindig könnyedén utoléri. (Mielőtt üldözőbe venné a párt, bemegy a kastélyába „harapni” valamit.) Kétszer megkegyelmez a feleség-visszarablónak mivel két életet ígért neki -, harmadszorra azonban megöli. A hős feltámad, és a boszorkánytól szerzett aranyszőrű táltosával (amelynek a sárkány táltosa az anyja) indul negyedszerre is feleségéért. A sárkány hiába üti a lovát buzogányával, hiába sarkantyúzza, az nem tudja utolérni az aranyszőrűt, a csikóját (Berze 1907).

Az előbbi mese egy puszta-hanyi variánsában Jankó a harmincharmadik szobában tizenkét fejű sárkányt talál aranyláncokra kötve. A sárkány három pohár vizet kér, melyektől megerősödik, elszakítja a láncokat, és elrabolja a „világszépasszonyt”, a hős feleségét. Jankó természetesen megszökteti az asszonyt elorzójától. A sárkány mindig este hét órára ér haza, a háromlábú táltosától ('tátosától') tudakolja meg, hogy hol van a felesége (ezen a ponton már a sárkányé), majd a megszokott módon eszik, iszik, alszik egyet, mielőtt a szerelmeseket lóháton üldözőbe veszi. Jankó hiába szökteti meg szíve hölgyét, a sárkány lova sokkal gyorsabb, mint az övé. Végül az asszony kifaggatja sárkány-urát, hogy hol szerezte a paripáját (az ördöngös asszonynál, szolgálatáért kapta), így Jankónak is sikerül egy még gyorsabb táltosra szert tenni. A sárkány elmegy a gépészhez, készíttet magának egy rettentő vasbuzogányt, amellyel lovát ütlegeli, hogy az gyorsabban vágtasson. Végül a ló nem bírja tovább a kínzást, leveti a hátáról a sárkányt (Berze 1907).

Egy másik változatban, a Tündérszép Ilonában a sárkány a tiltott szobában egy hordóba van zárva. Ebben a mesében a hős és a tizenkét fejű a felhők felett verekednek meg egymással (Berze 1907).

A Csinos Ágrágyiban égitestrabló sárkányokkal találkozunk: a tizenkét fejű a Napot, a kilencfejű a Holdat, a hétfejű pedig a csillagot rabolta el az égről, ezért az országban teljes a sötétség. A mesehős szembeszáll a sárkányokkal, akiknek emberi alakjához nem fér kétség. Lovon közlekednek, karddal küzdenek (Ágrágyi meg is kérdezi mindegyiktől, hogy ölre menjenek-e vagy karddal harcoljanak), ömlik róluk a verejték. A mese egy pontján pedig - mikor a legény a kilencfejűvel küzd - az olvasható, hogy előbbi levágja a sárkány „fejét”. A többes szám hiánya miatt felmerülhet az a gondolat, hogy talán a hét-, kilenc-, tizenkét fejű kifejezések csupán a sárkány félelmetes, grandiózus erejét jelzik, valójában nem is rendelkeznek több fejjel. A történet folytatásában a hős megöli a sárkányok feleségét, anyját, és apját is. Utóbbi magának akarja a legkisebb királylányt. A vén sárkány, miután meg is kapja a lányt, elárulja neki, hogy az ereje egy vaddisznó aranyhajszálában rejlik, így tudják végül elpusztítani (Berze 1907).

Egy másik változatban, a Borsszem Jankóban a hétfejű sárkány rézszőrű, a tizennégy fejű ezüstszőrű, a huszonnégy fejű pedig aranyszőrű paripán vágtat (Berze 1907).

A kis rák című népmesében a hétfejű sárkány egy erdei kastélyban lakik az anyjával, aki ebben a történetben nem gonosz boszorkány, hanem jó szándékú öregasszony: az 
odatévedt három fivért megpróbálja elrejteni fia elől. A sárkány viszont mindig megérzi az idegenek szagát, agyonüti őket, és felakasztja a kéménybe. Amikor egy kis rák - emberalakban - elmegy kiszabadítani a három ifjút, a sárkány alkut köt vele: ha több kőkenyeret meg tud enni, illetve több bort meg tud inni, mint ő, akkor hazaviheti a fiúkat. Mikor a sárkány annyira teleeszi magát, hogy már magatehetetlen, a hős agyonüti a buzogányával (Berze 1907).

A deákot erôvel királylyá teszik című mesében az ifjú deákhoz feleségül adják a királylányt, mert az öreg király és királyné azt hiszik, hogy a fiú királyfi. A deák azonban nagy bajba kerül: egy nap azt kérik tőle, mutassa meg az ő országát. Az ifjú ezért menekülőre fogja, de az erdőben egy hétfejű sárkány megsegíti: „Nem szükség elszökni; kár vóna! csak fojtasd útadot, s a mind az erdőből kiérsz, meglátsz egy lúdlábon forduló rézvárat, menny bé abba, s lakjál ott békével feleségestől, kutyástól, macskástól, addig, mig a vár mozogni s forogni kezd; de akkor osztán kotróggy onnét, met akkor én menyek oda haza, s ha benne kaplak, vége életednek." (Kriza 1863, 423) A sárkány két év múlva megy haza, akkor azonban egy vén banya (a hétfejü legfőbb ellensége, „kuruzsos királyné”) segít a deáknak, hogy az megtarthassa a várat (Kriza 1863).

Egy, a hütlen nővér típushoz tartozó besenyőteleki népmesében egy leány és bátyja a megörökölt erdei kunyhójukban élnek. A lány valamilyen ürüggyel mindig elküldi testvérét az erdőbe, mert „...ëgy tizënkétfejű sárkánt tartott a hordó alatt, a ki a szeretőji vót, hogy még a legény odajár, szerelmeskëdhessënek..." (Berze 1907, 105). A lány nemsokára már azon mesterkedik, hogy bátyját „eltegye az útból”, de a legény végül megöli a sárkány-szeretőt. A mese folytatásában a vízmegvonó, emberevő sárkány is előbukkan, amely típust a hüllőszerű sárkányok bemutatásakor már leírtunk (Berze 1907).

A négy egytestvér című mesében a négy fivér egy sárkány által elrabolt királylány kiszabadítására vállalkozik. A csillagász fiú belenéz a messzelátójába, és azt látja, hogy a leány éppen a sárkány ölében ül (Berze 1907).

A furfangos czigányban a sárkány a juhok gazdája. Az éhes cigány betér az istállóba, ráijeszt a sárkányra fenyegető beszédével, mire az meghívja a házukhoz, mondván, hogy rengeteg kenyerük van. A sárkány erejét és gyorsaságát össze akarja mérni a cigányéval. Mindig az anyjától kér tanácsot, hogy milyen próbák elé állítsa, de a cigány mindig túljár a sárkány eszén. A mese végén a cigánygyerekek felpofozzák a sárkányt (Berze 1907).

Mailand Oszkár Borsszemvitéz és szép Julia, a ki erdőt ződit s füvet virágoztat címú meséjében inkább antropomorf sárkánnyal találkozunk: „a huszonnégyfejü sárkány a tornáczban álldogál”; „Feleli a huszonnégyfejü sárkány: »Ehetem-e, ihatom-e, pipázhatom-e, tánczolhatom-e egyet s elérjük-e?«" (Mailand 1905); A sárkány többször lóra ül, s felesége is van. Az egyetlen motívum, amely más típusú szörnyre utal, az az, hogy a hétfejü „sárkányöccs” tüzet fúj: „ójan kék láng jő előre, hogy összeéget mindent” (Mailand 1905).

Érdekes, hogy ugyanennek a történetnek létezik egy változata Merényi László Sajóvölgyi eredeti népmesék című kötetében (Szép Miklós címmel). Ebben a sárkány alakja ugyan elsőre hasonlónak tűnik, ám itt csak az emberi attribútumokat ismerjük meg. A sárkánynak „,asszonya” van, lovagol, diót tör stb. Nincs szó ugyanakkor pikkelyes farokról vagy éppen tűzfújásról (Merényi 1862).

A mese egy további változatában, $A$ három királyfiban a hétfejü, tűzokádó sárkány a város melletti tóban lakik, aki minden héten egy szűzlányt követel (Erdélyi 1846). Ugyanakkor erről a fenevadról nagyon kevés dolgot tudunk meg, a királyfi gyorsan, könnyen legyőzi - akár ember-, akár állatszerű lény is lehet.

E történetekben gyakori közös pont, hogy a sárkány feleségként tekint az elrabolt lányokra, eleve ilyen céllal ragadja el őket. S bár a meseolvasó, -hallgató befogadó belső 
képalkotása valószínűleg ezúttal is gyíkszerű, repülő, tüzet fújó fenevadat eredményez, a szövegből sem direkt, sem indirekt módon nem kapunk erre megerősítést, sőt. Erről részletesebben később szólunk.

\section{Nehezen meghatározható sárkányalak}

Kutatásunk során néhány népmesében nem találtunk olyan utalást vagy egyértelmű információt, melyekből egyértelműen meg lehetne határozni a sárkány alakját.

A Halász Józsi című népmesében a szegény ifjú egy aranyhalat fog ki a vízből, amely szép kisasszonnyá változik. Később a főhőst a földesúr lehetetlen próbák elé állítja. Az asszony mindig pihenni küldi kétségbeesett férjét, majd az ostorával akkorát csettint, hogy hetedhét országon keresztül is hallatszik. Így hívja elő a világ összes sárkányát, akik minden parancsát teljesítik, és „fö’séges asszonyom”-nak szólítják. A lehetetlen próbákat a sárkányok végzik el Józsi helyett. Ugyanakkor semmit sem tudunk meg róluk (Kriza 1863).

A szárnyas farkasban egy gyönyörű királylány ágya előtt leláncolva hortyog egy hétfejű sárkány. A hős megszökteti a lányt, s mikor a sárkány a kapu becsapódására felébred, és észreveszi, hogy a lány nincs az ágyában, kínjában egész nap ordít. Nem fontos szereplője a történetnek - a helyét „átveszi” a szárnyas farkas, akit meglehetősen könnyen győz le a királyfi -, s vajmi keveset tudunk meg róla (Berze 1907).

Nem teljesen egyértelmű a sárkányok karaktere $A$ három királyfi, a három sárkány és a vas orrú bába címü mesében, amelyet Ipolyi adott közre. A történet három sárkánya hét-, nyolc-, illetve kilencfejű, őket kell legyőznie Ambrusnak, a legkisebb királyfinak. A küzdelem leírása alapján tipikus állati szörnyfigurák Ambrus ellenfelei, akiket annak rendje és módja szerint meg is öl a fiú. Kevésbé szokványos motívum, hogy Ambrusnak a bosszút esküvő feleségeket is meg kell ölnie, ahogy a sárkányok anyját, a „vas orrú bábát” is (Erdélyi 1848). A sárkányok viselkedése, cselekedeteik alapján lehetnek állatfigurák, ám az, hogy feleségük van, akik talán emberi lények (erről nem kapunk információt), nem erre utal. Gondolhatnánk, hogy a szövegben két mesét szőtt egybe a szóbeli közlő (ez nem ritka jelenség), ám a szüzsé nagyon hasonló változatban ismerős lehet máshonnan is. Lásd Az égitest-szabadító (AaTh 328A, BN 319). Szabó Szilvia szerint a mese keleti eredetű, a sárkányok pedig antropomorf alakok (Szabó 2008).

\section{Benedek Elek sárkányképe}

Miközben a magyar gyermek- és mesekultúra egyik legfontosabb alakja természetesen sok szempontból hasonló módszerrel, eredménnyel dolgozott, mint elődei és kortársai, e témában muszáj külön fejezetben tárgyalnunk az ő sárkányos meséit. Ennek nem csupán az az oka, hogy az egyik legnagyobb hatású gyűjtőről, íróról van szó, de ő az, akinél legegyértelműbben megfigyelhető a kontamináció, a szörny- és embersárkány attribútumainak keveredése egy-egy konkrét mesén belül. Míg az előző fejezetben előkerültek olyan történetek, amelyekben nehezen vagy nem meghatározható a sárkány típusa, Benedek Eleknél kétségtelen példák vannak a keveredésre is.

Vizsgálatunk forrása a Magyar mese- és mondavilág három kötete volt, ezek összesen 382 történetet tartalmaznak. Ezek közül 32-nek van sárkány szereplője. (A 'sárkány' szó ennél több szövegben is megtalálható, például van, ahol a puska kakasát - 'sárkányát' említi a szerző, illetve van, ahol csak megemlíti egy szereplő a sárkányt, de a cselekmény alakításában már nem vesz részt. Mi csak azokkal a mesékkel foglalkoztunk, ahol élő, a történet alakulásában aktív szereplő a sárkány.) Ezúttal a mondákat - például a Szent Anna tava - sem vettük figyelembe. 
Állat-, szörnyszerű sárkányfigurák vannak a következő mesékben:

- A fekete havas (AaTh 304): tűzfújó, emberevő, három-, öt-, és hétfejü, emberevő szörnyetegek, a főhős megküzd velük.

- Feketeország (AaTh 302): tűzfújó, hétfejű, a főhős megküzdött vele.

- A kicsi bojtár: hét-, tizennégy és huszonegy fejü, tűzfújó szörnyek, a bojtár nem öli meg őket, ezért segítenek neki.

- Tamás kocsis: az öregasszony házát egy „hétfejű sárkánykutya” őrzi. Mindössze egyszer említik meg.

- Sárga kicsi kígyó: tűzfújó, hétfejű őrző sárkány, nincs fontos szerepe.

- Világszép Sárkány Rózsa (AaTh 409B*): hídőrző sárkánykígyók.

- A világvándora herceg: hétfejű szörny, akit egy oroszlán segítségével győz le a főhős.

- Szép Miklós: mellékszereplőként a történetben van két strázsáló sárkánykígyó.

- A háromvadas királyfi (AaTh315, AaTh300): tizenkét fejü sárkány. A tóban lakik, s felszívja a vizet, ha nem kap mindennap egy lányt.

- Világszép nádszál kisasszony (AaTh 408): egy százfejű sárkány strázsál a kapunál.

- A zsoltáréneklő madár (AaTh 550): tűzfújó, tizenkét fejü sárkány, ő őrzi a madarat.

- A halhatatlanság országa: a sárkányok oroszlánokkal együtt őrzik a kaput.

- Vízi Péter és Vízi Pál (AaTh 303): tizenkét fejű sárkány, aki elapasztja a kutat, ha nem kap minden esztendőben egy leányt.

- Molnár Ferkó: tizenkét fejű sárkány (aki egy kígyónak az anyja). Fia megmentéséért cserébe teljesíti Ferkó kívánságát.

- A tüzmadár (AaTh 550): hétfejű sárkány, akivel megküzd a főhős.

- Ambrus királyfi: három emberevő sárkány, hét-, nyolc-, kilencfejűek, tüzet fújnak. Mindegyiknek van felesége, az anyjuk boszorkány.

- Az aranymadár: tűzfújó sárkányok, akik a folyókon lévő hidakat őrzik.

- Többsincs királyfi: kilenc- és tizenkét fejü, tűzfújó sárkánykutyák.

- Jankalovics: huszonnégy tűzfújó őrző sárkány.

Antropomorf sárkányok:

- Világszép Sárkány Rózsa (AaTh 409B*): a sárkánykirály feleséget rabolt, lovagol, megküzd a királyfival.

- A tizenhárom hattyú: Hétfejü sárkány(király), aki feleséget rabolt magának.

- Mezőszárnyasi (AaTh 300A. AaTh 328A): Hét-, tizenkét és huszonegy fejü, lányrabló sárkányok, lovagolnak is. A lányok feltételezhetően feleségek.

- Vas Laci (AaTh 312): Hét-, tizennégy és huszonegy fejű, lányrabló sárkányok. A huszonegy fejűnek felesége van, nyíllal is lő, ruhát hord, úszik is. „Ledobta a tó partjára a rozsdás kardját, le a ruháját s a ruhájával a szennyes inget is. Beleugrott a tóba, úszott a kacsa után." (Benedek 1989)

- Kondás Jankó (AaTh 314): Hét-, tizennégy és huszonnégy fejű sárkányok. Inkább közvetett információkból tudjuk meg, hogy antropomorf alakok. Jankó mindegyiknek felajánlja: „Ne hepciáskodjék kend, hanem üljön ide a tűz mellé, süssön szalonnát kend is!" (Benedek 1989)

- Szép Miklós: A tizenkét fejü sárkány diót tör, eszik, iszik, lovagol.

- Az elrabolt királykisasszony: két lányrabló sárkány, emberi sajátosságukra utal ez a részlet is: „Látod-e, ott ül a két sárkány s a királykisasszony, fehér lepedővel betakarva. Eredj oda, s ha eltalálod, hogy melyik a királykisasszony, viheted."

Nem meghatározható:

- A három aranygyürü: strázsáló sárkányok, szinte semmit sem tudunk róluk. 
- János diák: hétfejű sárkány, aki először segít János diáknak, majd megölné.

- Halász Józsi: afféle dzsinnként teljesítik uruk (jelen esetben az asszony) parancsait.

Kontamináció:

- Az égig érő fa (AaTh4689): Kilencfejü sárkány van a történetben, aki a királylányt veszi feleségül, ugyanakkor tüzet fúj („szakadt a láng mind a kilenc szájából”). Érdekes, hogy még ilyen részlet is előfordul: „mikor a sárkány a kisasszonnyal templomba megy, te maradj itthon" (Benedek 1989). De a történetben táncra is perdül a kilencfejü. A mesének egyébként közös gyökere lehet $A$ tetejetlen fa és a Tündérszép Ilona címü, korábban tárgyalt szövegekkel. Azokban egyértelműen antropomorf sárkány van.

- A táltos kecske (AaTH 321): Hét-, tizennégy és huszonegy fejü, tűzfújó sárkány, akik feleséget raboltak maguknak. Tipikus Benedek Elek-es keveredést látunk. Miközben felesége van, közben tűzfújó szörny: „jő a sárkány, hogy a szájából hetvenhét singnyire szakadt a veres láng" (Benedek 1989).

- Hajnal: Hét-, tizennégy és huszonnégy fejü, lányrabló sárkányok, aki kenyeret esznek, bort isznak. Ugyanakkor tűzfújók.

\section{Összegzés}

Bár általában nem gondolunk bele, ha feltesszük magunknak a kérdést, miért rabol magának feleséget egy sárkány, könnyen zavarba jöhetünk. A lányokat (vagy éppen legényeket) evő sárkány figuráját értjük, ahogy értjük a hidat, kaput őrző vagy a hős lelőtt legyőzendő akadályként álló szörny célját, motívumait is. A válasz azért nehéz, mert bár a magyar folklórkincsben többféle sárkánnyal találkozhatunk, mi mindegyiket ugyanúgy képzeljük el. A 'sárkány' - gyermek és felnőtt képzetében egyaránt - tüzet fújó, pikkelyes, repülő, gyíkszerű szörny. Kutatásunkkal arra a kérdésre is kerestük a választ, hol, mikortól veszítettük el az antropomorf sárkány képét?

Mert emberszerű sárkányok nyilvánvalóan léteznek, vizsgálataink során, a 19. századi mesegyűjteményeket górcső alá véve legalább kéttucatnyi szövegben találtunk ilyeneket. Ugyanakkor arra, hogy egy szövegkorpuszon belül két különböző típusú (állat-, illetve emberszerű) sárkánytulajdonság is megjelenjen, alig van példa. Ilyen egyértelmű keveredésre talán Mailand Oszkár Borsszemvitéz és szép Julia, a ki erdőt ződit s füvet virágoztat című történetét hozhatjuk példának. Itt a szörny maga mondja magáról, hogy „lelkes állat” (vagyis értelemmel bíró, emberszerű lény), felesége is van, s többször ül lóra a mesében. Ugyanakkor a történet egy pontján tüzet fúj: „Ekkor Borsszemvitéz megbujik a fa oldalához. Egyszer érzi, hogy ojan lángsütés jő reá, azt hiszi, hogy el kell olvadjon. Egyszer érkezik a hétfejü sárkány s teszi a fa oldalára a fejit." (Mailand 1905)

Hasonlóan egyértelmű kontaminációra csak Benedek Eleknél bukkantunk, nála azonban három mesében is.

A Vízi Péter és Vízi Pálban Merényi és Benedek Elek szövege (a sárkányos részt nézve) szinte szó szerint megegyezik, de van olyan különbség, amelyik nagyon fontos. Merényinél egyértelmű, hogy a sárkány megenné a királylányt: „S ezt a kerek föld legszebb virágát egy rút, tizenkét fejü sárkány gyomrába akarják eltemetni" (Merényi 1861). Ezzel szemben a Benedek-féle verzióban ez van: „a királykisasszonnyal elrepül nagy Sárkányországba" (Benedek 1989). Utóbbi inkább feleségrabló (emberszerű) sárkányra utalna.

A Hajnal című mese sárkányai tipikus feleségrablók, a történet írott változatában mindössze egyetlen mondat mond ellent antropomforf voltuknak: „abban a pillanatban jött már a hétfejű sárkány is, csakúgy szakadt a láng mind a hét szájából” (Benedek 
1989). Ugyanez a motívum hibádzik $A$ táltos kecskében is, a kifejezetten emberszerü szörnyeteg tüzet fúj.

S hogy miből adódhat ez a keveredés? Benedek Elek jó mesemondó volt, s mint ilyen, bizonyos nyelvi fordulatokat, frazémákat „vitt magával” meséről mesére. (Ahogy ez természetes például egy kezdőformulánál.) $S$ ha az egyik történetben jól hangzott a sárkány említésénél, hogy „csakúgy szakadt a láng mind a hét szájából”, vagy: „a szájából hetvenhét singnyire szakadt a veres láng”, hát használta ezt a formulát máskor is. Ott is, olyankor is, amikor ahhoz a sárkányhoz ez már nem illett volna. Ám évtizedek, századok alatt bizony, elmosódhattak a határok a különböző típusú mesék, a különböző szerepű sárkányok között.

Így aztán szép lassan bennünk, mesehallgatókban, -olvasókban elhalványodott az emberszerű sárkány képe. Még úgy is, hogy csak a fentebb említett szövegekben olvashatunk templomba járó, táncoló, diót törő vagy éppen szeretőnek használt sárkányról. S bár például az észak-magyarországi mesék (különösen az Ámi Lajos közreadta változatok) nyilvánvalóan nem sárkánygyíkokról beszélnek - előfordul, hogy a mesehős csak a történet végén, a másik szemébe nézve jön rá, hogy az egy sárkány... ${ }^{1}$-, mostanra a 'sárkány’ szóról többségünknek egy repülő, tüzet fújó, gyíkszerű lény képe ugrik be. Nyilván nem csupán Benedek Eleknek köszönhető ez, de neki komoly szerepe lehetett a kontaminációban.

\section{Irodalom}

Arany János (1861): Eredeti mesék-bírálat. Szépirodalmi Figyelő, 2(1), 6-7.; 2(2) 21-23.; 2(3), 35-38.; 2(4), 53-54.

Benedek Elek (1989): Magyar mese- és mondavilág I-III. Bp.: Móra. [Elektronikus kiad.] Magyar Elektronikus Könyvtár <URL: http://mek.oszk.hu/04800/04833/04833.htm [2019. 06. 14.]

Berze Nagy János (1907): Népmesék Heves- és Jász-Nagykun-Szolnok megyéből. Bp.: Athenaeum.

Boldizsár Ildikó (1997): Varázslás és fogyókúra : Mesék, mesemondók, motívumok. Bp.: Kijárat Kiadó.

Domokos Mariann (2005): Gaal György mesegyűjteménye : Kiadott és kéziratban maradt mesék a 19. századból. Palimpszeszt, 11(24), [online] <URL: http://magyar-irodalom.elte.hu/palimpszeszt/24_szam/03.html\#fnB62 [2017.10.11.] Domokos Mariann (2008): Mesemondók és mesegyűjtők a 19. században: Marosi Gergely és mesélői. In: Gulyás Judit (szerk.): Tanulmányok a 19. századi magyar szövegfolklórról. Bp.: ELTE BTK Folklore Tanszék, pp. 242-278.

Domokos Mariann - Gulyás Judit (2009): Az Arany-család mesekéziratainak és Arany László Eredeti népmesék címü müvének kritikai kiadásáról. In: Etno-Lore [online] <URL: https://nti.btk.mta.hu/images/evkonyv/2009/domokosmarianngulyasjudit.pdf [2017. 10. 12.]

Dömötör Tekla (1981): A magyar nép hiedelemvilága. Budapest: Corvina Kiadó.

Erdélyi János (1846): Népdalok és mondák. I. kötet. Pest: [s. n.]

Erdélyi János (1848): Népdalok és mondák. III. kötet. Pest: [s. n.]

Erdész Sándor szerk. (1968): Ámi Lajos meséi I. Bp.: Akadémiai.

\footnotetext{
${ }^{1}$ Ámi Lajos meséinek közreadója ezt írja: „Ámi sárkánya nem kígyó vagy valamilyen antropomorf állatalak, hanem két lábon járó, külső kinézetre, ruházatra velünk teljesen megegyező ember.” (Erdész szerk. 1968: 71)
} 
Gombos Péter (2017): A 19. századi magyar mesegyűjtők és az irodalmi népmese : A népmese és a műmese alapvető műfaji kérdéseiről. Könyv, Könyvtár, Könyvtáros, 26(11), 46-52.

Kálmány Lajos (szerk.) (1914): Ipolyi Arnold népmesegyűjteménye. Bp.: KisfaludyTársaság. In: Wikisource vonatkozó oldalai [online] cop. 2009. <URL:

https://hu.wikisource.org/wiki/A_h\%C3\%A1rom_kir\%C3\%A1lyfi,_a_h\%C3\%A1rom_s\%C3\%A1 rk\%C3\%A1ny_\%C3\%A9s_a_vas_orr\%C3\%BA_b\%C3\%A1ba [2019. 07. 12.]

Kandra Kabos (1897): Magyar mythologia. Eger: Pásztor Bertalan [magánkiad.].

Kazinczy Gábor (szerk.) (1852): Nagyajtai Cserei Mihály Históriája. Pest: Emich Gusztáv Könyvnyomdája. [Elektronikus kiad.] Magyar Elektronikus Könyvtár (2008. 02. 04.) <URL: http://mek.oszk.hu/05600/05632/05632.pdf [2019. 02. 11.]

Kovács Ágnes (1961): Benedek Elek és a magyar népmesekutatás. Etnographia, 72(3), 430-443.

Kriza János (1863): Vadrózsák : Székely népköltési gyűjtemény. Kolozsvár: [s. n.].

Mailand Oszkár (1905): Székelyföldi gyüjtés. Bp.: Athéneum. [Elektronikus kiad.] Magyar Elektronikus Könyvtár <URL: http://mek.oszk.hu/11500/11578/11578.htm [2019. 07. 12.]

Merényi László (1861): Eredeti népmesék. Pest: Heckenast Gusztáv. [Elektronikus kiad.] Magyar Elektronikus Könyvtár <URL: http://mek.oszk.hu/08100/08132/08132.htm\#4 [2019. 06. 13.]

Nagy Olga (1984): Hősök, csalókák, ördögök. Bukarest: Kriterion Könyvkiadó.

Pál József - Újvári Edit (szerk.) (1997): Szimbólumtár : Jelképek, motívumok, témák az egyetemes és a magyar kultúrából. Bp.: Balassi Kiadó.

Róheim Géza (1911): Sárkányok és sárkányölő hősök. In: Uő: $A$ bűvös tükör. Bp.: Magvető Kiadó.

Solymossy Sándor (1931): Népmeséink sárkányalakja. Ethnographia, 42(3), 113-132.

Szabó Szilvia (2008): Bábák, banyák és boszorkányok : A népmesék mitikus-vallási elemeinek néprajzi interpretációi. [szakdolgozat] Szeged: Szegedi Tudományegyetem Bölcsészettudományi Kar.

Varga János (1877): A babonák könyve. [online] In: SZTE Egyetemi Digitális Archívum honlapja. Szeged: SZTE Egyetemi Digitális Archívum (cop. 2017. 10. 12.) <URL: http://misc.bibl.u-szeged.hu/23804/1/koll_009_015_001210.pdf [2019.02.07.]

Vargyas Lajos (1988): Magyar néprajz V. : Népköltészet. Bp.: Akadémiai. [Elektronikus kiad.] Arcanum Adatbázis <URL: https://www.arcanum.hu/hu/onlinekiadvanyok/MagyarNeprajz-magyar-neprajz-2/v-magyar-nepkolteszet-63D6/a-mesees-hiedelemvilag-kapcsolata-6785/mitikus-lenyek-679F/sarkany-67A2/ [2019. 07. 23.] Vígh Éva szerk. (2019): Állatszimbólumtár. Bp.: Balassi.

\section{Dragon image in Hungarian folk tale treasury Anatomy of a contamination}

During our research we wanted to know how the image of the dragon is represented in Hungarian folk tales, or more generally in Hungarian popular belief. More closely we were curious how and when the figure of the animal-like (lizard-like) firedrake and the figure of the (man-like) folk tale character who kidnaps girls mingled. We guessed that originally these two types of dragons had existed separately (in stories) and contamination could happen only later, as a result of which we do not wonder today why a flying firedrake kidnaps a wife for himself. 
For our research we have reviewed from among the first 19th century Hungarian folk tale collections the ones of László Arany, Elek Benedek, János Berze Nagy, János Erdélyi, Arnold Ipolyi, János Kriza, Oszkár Mailand and László Merényi. We have grouped the tales containing dragons found in them and we have drawn our conclusions according to the figures of the dragons based on the results concerning the time and way of mingling.

Kulcsszavak: folk tale, dragon image, contamination, Elek Benedek 